\title{
Use of a New Deep Vertical Gypsum Placement Practice on Corn and Soybean Production in Conservation Tillage Systems
}

\author{
Theodore G. Blumenschein ${ }^{1}$, Kelly A. Nelson ${ }^{2}, \&$ Peter P. Motavalli ${ }^{1}$ \\ ${ }^{1}$ School of Natural Resources, University of Missouri, Columbia, MO, USA \\ ${ }^{2}$ Division of Plant Sciences, University of Missouri, Novelty, MO, USA \\ Correspondence: Peter P. Motavalli, School of Natural Resources, University of Missouri, Columbia, MO 65211, \\ USA. Tel: 1-573-884-3212. E-mail: motavallip@missouri.edu
}

Received: June 17, 2018

doi:10.5539/jas.v10n11p1
Accepted: August 14, $2018 \quad$ Online Published: October 15, 2018

URL: https://doi.org/10.5539/jas.v10n11p1

\begin{abstract}
Corn (Zea mays L.) and soybean (Glycine max (L.) Merr.) production in claypan soils in the north central U.S. may be constrained by the presence of acidic subsoils. Subsoil acidity can inhibit root growth leading to decreased drought tolerance and grain yields. In conservation tillage systems, management options to incorporate gypsum applications may be limited; thereby reducing available practices to lower subsoil acidity. The objective of this study was to determine the effects of surface placement of gypsum compared to a new practice for deep vertical placement of gypsum on corn and soybean plant growth and yields in a conservation tillage system. Field trials were conducted from 2012 to 2016 in northeast Missouri (USA) with treatments of gypsum (0, 2.9, and $5.2 \mathrm{Mg} \mathrm{ha}^{-1}$ ) broadcast on the soil surface or applied in a deep vertical band to a depth of $51 \mathrm{~cm}$. Surface and deep banding of gypsum had inconsistent effects on corn and soybean plant heights, plant population and yields. However, deep banding of gypsum resulted in a 6.4 to $9.8 \%$ decrease in corn yields and a 9.9 to $13.0 \%$ decrease in soybean yields depending on the time after application. These results indicate that further research is warranted in conservation tillage systems in claypan soils to examine modification to the deep vertical placement practice or combining applications of surface-applied gypsum and deep placement of lime in order to develop a practice that will be more effective in overcoming subsoil acidity.
\end{abstract}

Keywords: gypsum, conservation tillage, deep placement, claypan, acidic subsoil

\section{Introduction}

Soil acidity is a major constraint to increased global agricultural productivity and this acidity is projected to increase in developing nations where atmospheric sulfur emissions have risen rapidly (Sumner et al., 1986; Tupper et al., 1987; Mclay et al., 1994; Farina et al., 2000a, 2000b; Kuylenstierna et al., 2001; Godsey et al., 2007). In addition, soils under intense cropping systems may have substantial increases in subsoil acidity with depth (Abruña et al., 1964; Adeoye \& Singh, 1984).

In areas with low levels of soil calcium $(\mathrm{Ca})$ and elevated exchangeable aluminum $\left(\mathrm{Al}^{+3}\right)$ resulting from acidic soil conditions, treatments of gypsum $\left(\mathrm{CaSO}_{4}\right)$ or gypsum byproducts, such as flue gas desulfurization gypsum, have shown to be effective in ameliorating these limitations to crop growth and development (Sumner et al., 1986; Farina et al., 2000a, 2000b; Wang \& Yang, 2018). Use of gypsum instead of lime for acidity amelioration in no-till or conservation systems has an advantage because gypsum can be surface-applied and leach into the subsoil whereas a surface lime application has limited effect on the subsoil (Caires et al., 2011). Solubility of gypsum is roughly 200 times greater than the calcium carbonate found in limestone allowing surface applications to affect subsoil properties (Rengel, 2003). Overall advantages of gypsum application in agricultural fields include prevention and correction of sodicity, greater stability of soil organic matter, more stable soil aggregates, improved water penetration into soil, increased levels of soil $\mathrm{Ca}$ and $\mathrm{S}$ for plant use, and more rapid seed emergence (Wallace, 1994; Watts \& Dick, 2014).

Decreases in atmospheric $\mathrm{S}$ deposition and increases in cropping intensity with little $\mathrm{S}$ fertilizer inputs in some regions of the world has resulted in an increased incidence of plant $S$ deficiency (Chen \& Dick, 2011). Response to gypsum applications as a source of S has been widely reported for several crops (Seim et al., 1969; O’Leary \& Rehm, 1990; Chen et al., 2005). 
Increased crop yield responses to gypsum have also been credited for a reduction of soluble $\mathrm{Al}^{+3}$ and additions of $\mathrm{Ca}$ to the soil after gypsum was applied. Although gypsum has little to no effect on soil acidity, gypsum applications greatly reduce $\mathrm{Al}^{+3}$ toxicities in the soil (Mclay et al., 1994). The precise mechanism behind the immobilization of $\mathrm{Al}^{+3}$ is not well understood, but it is suggested to occur through various complex reactions (Mclay et al., 1994). For example, the sulfate in gypsum may react with $\mathrm{Al}^{+3}$ to form aluminum hydroxyl sulfate minerals that precipitate out of the soil solution (Nordstrom, 1982). Others propose that decreases in Al:Ca ratios from additions of calcium from gypsum resulted in higher calcium-aluminum complexes causing a reduction of $\mathrm{Al}^{+3}$ in the soil solution (Ritchey et al., 1980).

Regardless of the pathway for $\mathrm{Al}^{+3}$ reduction caused by gypsum application, it is essential that surface amendments leach downward into the subsoil for subsoil amelioration to occur (Mclay et al., 1994). In a study by Toma et al. (1999), the long term beneficial effects of incorporated and surface-applied gypsum on ferruginous and aluminous soils under corn and alfalfa management continued to occur 16 years after application. Furthermore, corn grain yields increased 29 to $50 \%$ over the period of 16 years after treatment.

Successful improvements to soil fertility from gypsum amendments on highly weathered tropical soils are not often observed on less weathered, but equally acidic soils (Sumner, 1995; Farina et al., 2000a, 2000b). Greater soil fertility and lower levels of active $\mathrm{Al}^{+3}$ found in less weathered soils resulted in little to no beneficial effects from gypsum treatments. Soil orders, such as Alfisols, Oxisols, and Ultisols, are often characterized by a stratification of increasing soil acidity with depth in the soil profile resulting in low and sometimes unsustainable crop yields (Farina et al., 2000a, 2000b; Sumner \& Yamada 2002; Rengel, 2003). In a literature review, Watts and Dick (2014) indicated that gypsum applications are generally most beneficial for agriculture in sodic soils, clayey soils with poor drainage, soils containing acidic subsoils, and soils where there is deficient $\mathrm{Ca}$ and $\mathrm{S}$.

In order to effectively reduce subsoil acidity under no-till and conservation tillage practices, lime amendments may be directly applied to the subsoil. However, gypsum applications have often been surface-applied or shallowly incorporated because of the potential of this product to leach into the subsoil (Farina \& Channon, 1988). There has been little research investigating the effects of new practices for gypsum placement on yield response of corn and soybean under a conservation tillage system in less weathered, but equally acidic soils. A related study using the same deep vertical placement practice utilized in this research, but for deep lime placement, indicated that this practice raised corn yields by as much as $1.3 \mathrm{Mg} \mathrm{ha}^{-1}$ in low rainfall years and was less effective in soybean production and in higher rainfall years (Blumenschein et al., 2018). The objective of this research was to evaluate the impacts of gypsum placement, including use of a new deep placement practice, at differing rates on corn and soybean plant growth and grain yields in a conservation tillage system situated in poorly drained claypan soils that exhibit subsoil acidity.

\section{Method}

\subsection{Site Description and Experimental Design}

Three field trials were established on poorly drained claypan soils from 2012 to 2014 at the Greenley Memorial Research Center $\left(40^{\circ} 02^{\prime} \mathrm{N}, 92^{\circ} 20^{\prime} \mathrm{W}\right)$ near Novelty, Missouri (USA). Claypan soils are characterized by an argillic horizon with a content of 40 to $50 \%$ smectitic clays situated between 10 to $80 \mathrm{~cm}$ below the soil surface (Udawatta et al., 2004). They often exhibit a sudden stratification in soil $\mathrm{pH}$ with an optimal surface horizon and acidic subsoil from 20 to $50 \mathrm{~cm}$ with $\mathrm{pH}$ values categorized as acidic ranging from 3.6 to 4.5 for the Putnam, Kilwinning, Mexico and Armstrong soil series (Ferguson, 1995).

Field Trials \#1 and \#3 were established in the spring of 2012 and the fall of 2013 on a Putnam silt loam (fine, smectitic, mesic Vertic Albaqualfs). Field Trial \#2 was established in the fall of 2012 on a Kilwinning silt loam (fine, smectitic, mesic, Vertic Epiaqualfs). Prior to the study, experimental sites were under continuous no-till production for over 13 years. Sites with acidic surface and subsoil horizons were utilized for this experiment. Initial soil characteristics were taken at the establishment of each trial and are presented in Table 1.

A randomized complete block design was used for the three field trials with 12 treatments replicated four times. Plot sizes were $4.6 \times 24.4 \mathrm{~m}$ for trials 1 and 3 , and $4.6 \times 22.9 \mathrm{~m}$ for trial $\# 2$. A factorial arrangement of treatments included two crops (corn and soybean), two placement methods (surface and deep banding), and rates of gypsum $\left(0,2.9\right.$, and $\left.5.2 \mathrm{Mg} \mathrm{ha}^{-1}\right)$. The crops evaluated in this experiment were corn and soybean planted in rotation for subsequent years. Methods of placement included a surface broadcasted or a deep banding incorporation of pelletized gypsum at four depths $(0-13,13-25,25-38$ and 38-51 cm) simultaneously. Depths were selected to be similar to past literature (Tupper et al., 1987; Farina et al., 2000a, 2000b). For mechanical application purposes, pelletized gypsum was used instead of traditional powder amendments. 
Deep banding was accomplished using a conservation subsoiler (Case IH Ecolo-Til ${ }^{\circledR} 2500$, Goodfield, IL) with a custom built shank attachment designed to deliver gypsum at desired depths (Figure 1). Gypsum application rates were selected based on the average subsoil recommendation $\left(5.2 \mathrm{Mg} \mathrm{ha}^{-1}\right)$ and the average top $15 \mathrm{~cm}$ of soil recommendation $\left(2.9 \mathrm{Mg} \mathrm{ha}^{-1}\right)$. The gypsum source was comprised of pelletized gypsum (Kelly's Gypsum, Kirksville, MO) derived from mined gypsum containing $76.0 \%$ calcium sulfate dihydrate $\left(\mathrm{CaSO}_{4} \cdot 2 \mathrm{H}_{2} \mathrm{O}\right)$.

Gypsum treatments were applied using a commercial Montag dry fertilizer air delivery system (Emmetsburg, IA). Conservation zone tillage knives were spaced $76 \mathrm{~cm}$ apart, congruent with standard corn row spacing. Greater soil disturbance from vertical gypsum placement was observed compared to normal conservation vertical tillage. Surface tillage with a Tilloll 875 (Landoll Corp., Marysville, KS) followed deep vertical placement treatments to smooth the soil surface prior to planting; however, no additional tillage was performed the following years after application of treatments. Uniform broadcast surface applications were achieved by running a conservation tiller with custom shank above the soil surface to insure application consistency. Strips of corn or soybean were randomly assigned at trial establishment and rotated in subsequent years. Each crop strip (main plot) was randomly divided into two additional strips (sub-plot) of surface-applied and deep vertical placed gypsum. Deep vertical placement and surface applied strips were then divided into plots of varying rates of gypsum (sub-sub-plots), resulting in a split-split randomized complete block design.

Table 1. Initial average soil characteristics ( \pm standard deviation) at different depths for the Trial \#1, \#2 and \#3 established in 2012, 2013, and 2014, respectively

\begin{tabular}{|c|c|c|c|c|}
\hline \multirow{2}{*}{ Soil characteristics } & \multicolumn{4}{|c|}{ Soil depth } \\
\hline & $0-13 \mathrm{~cm}$ & $13-25 \mathrm{~cm}$ & $25-38 \mathrm{~cm}$ & $38-51 \mathrm{~cm}$ \\
\hline \multicolumn{5}{|l|}{ Trial \#1 } \\
\hline $\mathrm{pH}_{\mathrm{s}}\left(0.01 M \mathrm{CaCl}_{2}\right)$ & $5.6 \pm 0.2$ & $5.6 \pm 0.4$ & $4.6 \pm 0.2$ & $4.6 \pm 0.2$ \\
\hline Neutralizable acidity $\left(\mathrm{cmol}_{\mathrm{c}} \mathrm{kg}^{-1}\right)$ & $3.5 \pm 2$ & $2.9 \pm 1$ & $8.5 \pm 1.6$ & $6.8 \pm 1.0$ \\
\hline Organic matter $\left(\mathrm{g} \mathrm{kg}^{-1}\right)$ & $27 \pm 3$ & $23 \pm 1$ & $23 \pm 3$ & $22 \pm 2$ \\
\hline Bray $1 \mathrm{P}\left(\mathrm{kg} \mathrm{ha}^{-1}\right)$ & $17.4 \pm 9.8$ & $5.0 \pm 1.4$ & $3.9 \pm 1.9$ & $14.6 \pm 4.5$ \\
\hline $\mathrm{Ca}\left(\mathrm{kg} \mathrm{ha}^{-1}\right)$ & $4,427 \pm 347$ & $5,200 \pm 661$ & $5,257 \pm 706$ & $4,988 \pm 673$ \\
\hline $\operatorname{Mg}\left(\mathrm{kg} \mathrm{ha}^{-1}\right)$ & $494 \pm 98$ & $689 \pm 189$ & $981 \pm 138$ & $996 \pm 158$ \\
\hline $\mathrm{K}\left(\mathrm{kg} \mathrm{ha}^{-1}\right)$ & $178 \pm 12$ & $173 \pm 28$ & $226 \pm 32$ & $231 \pm 16$ \\
\hline $\operatorname{CEC}\left(\mathrm{cmol}_{\mathrm{c}} \mathrm{kg}^{-1}\right)$ & $15.4 \pm 2.3$ & $17.3 \pm 3.2$ & $24.2 \pm 3.2$ & $22.0 \pm 2.3$ \\
\hline \multicolumn{5}{|l|}{$\underline{\text { Trial \#2 }}$} \\
\hline $\mathrm{pH}_{\mathrm{s}}\left(0.01 M \mathrm{CaCl}_{2}\right)$ & $5.0 \pm 0.1$ & $5.0 \pm 0.5$ & $4.9 \pm 0.7$ & $4.9 \pm 0.8$ \\
\hline Neutralizable acidity $\left(\mathrm{cmol}_{\mathrm{c}} \mathrm{kg}^{-1}\right)$ & $5.1 \pm 0.5$ & $4.9 \pm 1.9$ & $6.9 \pm 4.0$ & $6.8 \pm 3.8$ \\
\hline Organic matter $\left(\mathrm{g} \mathrm{kg}^{-1}\right)$ & $30 \pm 6$ & $19 \pm 4$ & $18 \pm 3$ & $14 \pm 4$ \\
\hline Bray $1 \mathrm{P}\left(\mathrm{kg} \mathrm{ha}^{-1}\right)$ & $127.2 \pm 46.2$ & $19.1 \pm 10.7$ & $11.5 \pm 4.0$ & $30.8 \pm 19.4$ \\
\hline $\mathrm{Ca}\left(\mathrm{kg} \mathrm{ha}^{-1}\right)$ & $2,841 \pm 312$ & $3,263 \pm 690$ & $4,138 \pm 1,828$ & $4,144 \pm 1,678$ \\
\hline $\operatorname{Mg}\left(\mathrm{kg} \mathrm{ha}^{-1}\right)$ & $307 \pm 91$ & $415 \pm 192$ & $739 \pm 452$ & $848 \pm 420$ \\
\hline $\mathrm{K}\left(\mathrm{kg} \mathrm{ha}^{-1}\right)$ & $594 \pm 240$ & $159 \pm 47$ & $179 \pm 77$ & $233 \pm 85$ \\
\hline $\mathrm{CEC}\left(\mathrm{cmol}_{\mathrm{c}} \mathrm{kg}^{-1}\right)$ & $13.3 \pm 1.4$ & $13.9 \pm 3.3$ & $19.1 \pm 6.4$ & $19.4 \pm 4.8$ \\
\hline \multicolumn{5}{|l|}{ Trial \#3 } \\
\hline $\mathrm{pH}_{\mathrm{s}}\left(0.01 M \mathrm{CaCl}_{2}\right)$ & $6.1 \pm 0.1$ & $6.2 \pm 0.1$ & $5.0 \pm 0.2$ & $4.6 \pm 0.1$ \\
\hline Neutralizable acidity $\left(\mathrm{cmol}_{\mathrm{c}} \mathrm{kg}^{-1}\right)$ & $1.8 \pm 0.5$ & $1.9 \pm 0.3$ & $7.1 \pm 1.9$ & $12.3 \pm 1.9$ \\
\hline Organic matter $\left(\mathrm{g} \mathrm{kg}^{-1}\right)$ & $23 \pm 5$ & $21 \pm 2$ & $23 \pm 4$ & $27 \pm 3$ \\
\hline Bray $1 \mathrm{P}\left(\mathrm{kg} \mathrm{ha}^{-1}\right)$ & $10.4 \pm 4.7$ & $5.6 \pm 2.2$ & $2.0 \pm 0.6$ & $1.1 \pm 0$ \\
\hline $\mathrm{Ca}\left(\mathrm{kg} \mathrm{ha}^{-1}\right)$ & $3,954 \pm 957$ & $3,646 \pm 289$ & $4,497 \pm 434$ & $5,223 \pm 384$ \\
\hline $\operatorname{Mg}\left(\mathrm{kg} \mathrm{ha}^{-1}\right)$ & $398 \pm 158$ & $377 \pm 58$ & $749 \pm 142$ & $1226 \pm 80$ \\
\hline $\mathrm{K}\left(\mathrm{kg} \mathrm{ha}^{-1}\right)$ & $154 \pm 30$ & $136 \pm 12$ & $220 \pm 36$ & $349 \pm 28$ \\
\hline $\mathrm{CEC}\left(\mathrm{cmol}_{\mathrm{c}} \mathrm{kg}^{-1}\right)$ & $12.2 \pm 3.2$ & $11.6 \pm 0.8$ & $20.2 \pm 3.2$ & $28.9 \pm 2.7$ \\
\hline
\end{tabular}




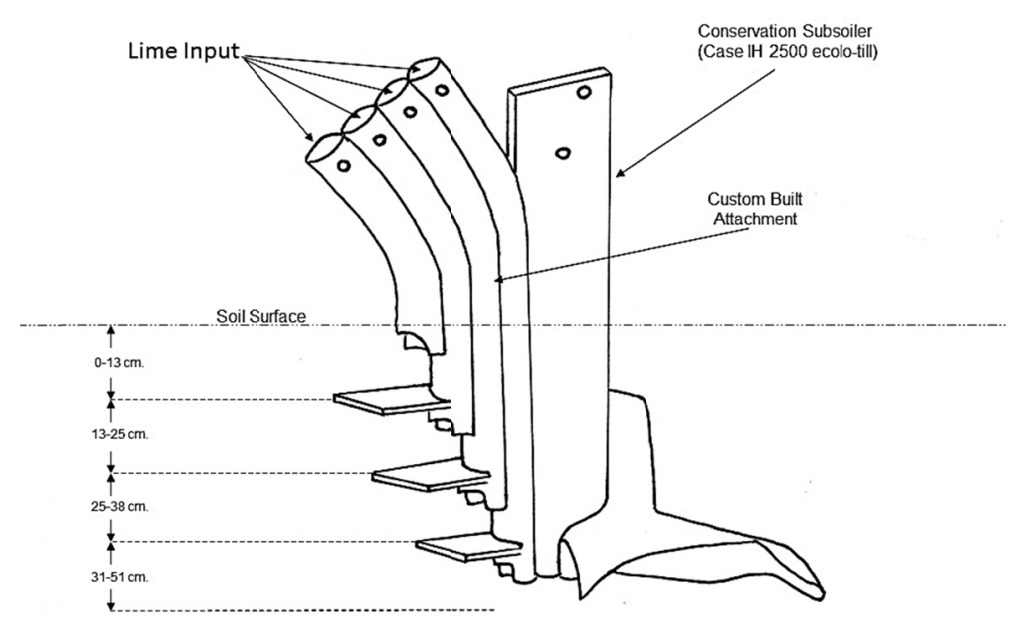

Figure 1. Custom built shank attachment schematics showing the depths at which gypsum was placed in the soil in relation to the soil surface (Blumenschein et al., 2018)

Treatment abbreviations used in the following text and on all figures and tables for gypsum treatments are as follows:

CTRL: No application of gypsum/no tillage;

S-LO: Surface application of gypsum at $2.9 \mathrm{Mg} \mathrm{ha}^{-1}$ and no-tillage;

S-HI: Surface application of gypsum at $5.2 \mathrm{Mg} \mathrm{ha}^{-1}$ and no-tillage;

D-NO: Deep vertical tillage with no application of gypsum;

D-LO: Deep vertical gypsum placement at $2.9 \mathrm{Mg} \mathrm{ha}^{-1}$;

D-HI: Deep vertical gypsum placement at $5.2 \mathrm{Mg} \mathrm{ha}^{-1}$.

\subsection{Management}

In the spring of 2012, gypsum treatments were applied to Trial \#1 followed by planting of corn and soybean. In the fall of 2012, gypsum treatments were applied to Trial \#2 with planting of corn and soybean the following spring of 2013 for Trials \#1 and \#2. In the fall of 2013, gypsum treatments for Trial \#3 were applied with corn and soybean being planted the following spring of 2014 for Trials \#1, \#2 and \#3. Corn was planted in each trial in $76 \mathrm{~cm}$ wide rows at 72,140 seeds ha ${ }^{-1}$. All corn trials from 2012 to 2016 received recommended $\mathrm{N}$ fertilizer rates for corn production in Missouri at 135 to $235 \mathrm{~kg} \mathrm{~N} \mathrm{ha}^{-1}$ as either broadcast urea or polymer-coated urea (ESN, Agrium, Loveland, CO), or injected anhydrous ammonia (Buchholz et al., 1983). For soybean trials, the row spacing was 19 to $38 \mathrm{~cm}$ and seeding rate was 440,000 seeds ha ${ }^{-1}$. Additional fertilizer was added in the form of 20-80-140-20-2 $\mathrm{kg} \mathrm{ha}^{-1}$ N-P-K-S-Zn (MicroEssentials SZ, Mosaic, Plymouth, MN) or 15-73-129 $\mathrm{kg} \mathrm{ha}^{-1}$ N-P-K as monoammonium phosphate to corn and soybean trials when required based on soil test results. All plots were maintained weed-free using burndown, preemergence, and postemergence herbicides.

\subsection{Soil Sampling and Analysis}

Initial soil samples were taken at the establishment of each trial using a Giddings hydraulic probe (Giddings Machine Company, Windsor, $\mathrm{CO}$ ) prior to $\mathrm{P}$ and $\mathrm{K}$ fertilizer and treatment applications and were separated into depths of 0-13, 13-28, 25-38, and 38-51 cm. Samples were analyzed by the University of Missouri Soil and Plant Testing Laboratory using standard methods (Nathan et al., 2006).

\subsection{Plant Measurements}

Plant heights were recorded between September and October of each year after corn plants had reached the VT growth stage. Plant populations were calculated based on middle row stand counts for corn and a middle of plot stand count for a $1.2 \mathrm{~m}$ length of row for soybean. The center two rows of corn plots were harvested using a plot combine (Wintersteiger Delta, Salt Lake City, UT) and grain yields were adjusted to $150 \mathrm{~g} \mathrm{~kg}^{-1}$ moisture. For plots planted to soybean, the center $1.5 \mathrm{~m}$ of the soybean plot was harvested using a plot combine (Wintersteiger Delta, Salt Lake City, UT) and yields adjusted to $130 \mathrm{~g} \mathrm{~kg}^{-1}$ moisture. Yield percent differences were calculated by comparing the means of treatment plots within each replication of a trial with the non-treated control means 
of the same replications within the trial. Percent differences from control plots were grouped into years after application and averaged for each treatment.

\subsection{Statistical Analysis}

Data were analyzed using analysis of variance (ANOVA) and comparisons among treatment means were made using Fisher's protected least significant difference (LSD) at $\mathrm{P}<0.10$. Statistical procedures were carried out with SAS statistical software (SAS Institute Inc., 2013).

\section{Results}

\subsection{Climatic and Environmental Conditions}

Climatic conditions at the field sites varied among growing seasons. Rainfall over the growing seasons (Figure 2) for 2012, 2013 and 2016 were 275, 26 and $188 \mathrm{~mm}$ below the 10-year average of $699 \mathrm{~mm}$, respectively. Although 2013 rainfall over the growing season was only slightly below average, the majority of the precipitation occurred over the course of a few events and an extended dry period persisted from early July to September. Rainfall for 2014 and 2015 was 48 and $212 \mathrm{~mm}$ above the 10-year average, respectively. These seasonal differences in rainfall may account for some of the observed differences in grain yields for both corn and soybean over the cropping years.

\subsection{Crop Response}

\subsubsection{Corn}

Corn plant heights for all the gypsum treatments in Trials \#1, \#2 and \#3 from 2012 to 2014 are reported in Table 2. There were significant differences in corn plant heights among treatments in 2012 and 2014 for Trial \#1. No significant treatment differences compared to the control were observed in 2012, 2013 and 2014 for Trial \#1. In 2014, no significant differences between treatments were observed for both Trials \#2 and \#3.

Corn plant populations for gypsum treatments are reported in Table 3. Plant populations were decreased by the deep vertical placement of gypsum at $2.9 \mathrm{Mg} \mathrm{ha}^{-1}$ by 11,300 plants $\mathrm{ha}^{-1}$ in 2012 for Trial \#1. No significant differences in plant population were observed among treatments in 2013 and 2014 for Trial \#1. During the 2015 growing season, surface applied gypsum at $2.9 \mathrm{Mg} \mathrm{ha}^{-1}$ decreased plant populations by 3,400 plants $\mathrm{ha}^{-1}$, where as in 2016, deep vertically placed gypsum at 2.9 and $5.2 \mathrm{Mg} \mathrm{ha}^{-1}$ decreased plant populations 8,000 and 11,800, respectively. No significant differences in plant populations were observed between the gypsum treatments and the control plots for Trial \#2 from 2012 to 2016. Trial \#3 had no significant differences among treatments in 2014 and 2016. However, deep gypsum placement at $5.2 \mathrm{Mg} \mathrm{ha}^{-1}$ reduced plant populations 3,800 plants ha ${ }^{-1}$ compared to the non-treated control in 2015.

Differences in corn grain yields between treatments for all three field trials are presented in Figures 3 to 6 . In the first and second year of Trial \#1, corn grain yields were not affected by deep vertically placed gypsum compared to the control (Figure 3). By the third year, deep vertical placed gypsum at $5.2 \mathrm{Mg} \mathrm{ha}^{-1}$ had a $1.1 \mathrm{Mg} \mathrm{ha}{ }^{-1}$ reduction in corn yields in Trial \#1 compared to the control. In 2015, no treatments resulted in significant differences in grain yields compared to control plots for Trial \#1. Five years after treatment in Trial \#1, deep vertically placed gypsum at 2.9 and $5.2 \mathrm{Mg} \mathrm{ha}^{-1}$ had corn yields that were 1.4 and $1.1 \mathrm{Mg} \mathrm{ha}^{-1}$ less than the control, respectively. 


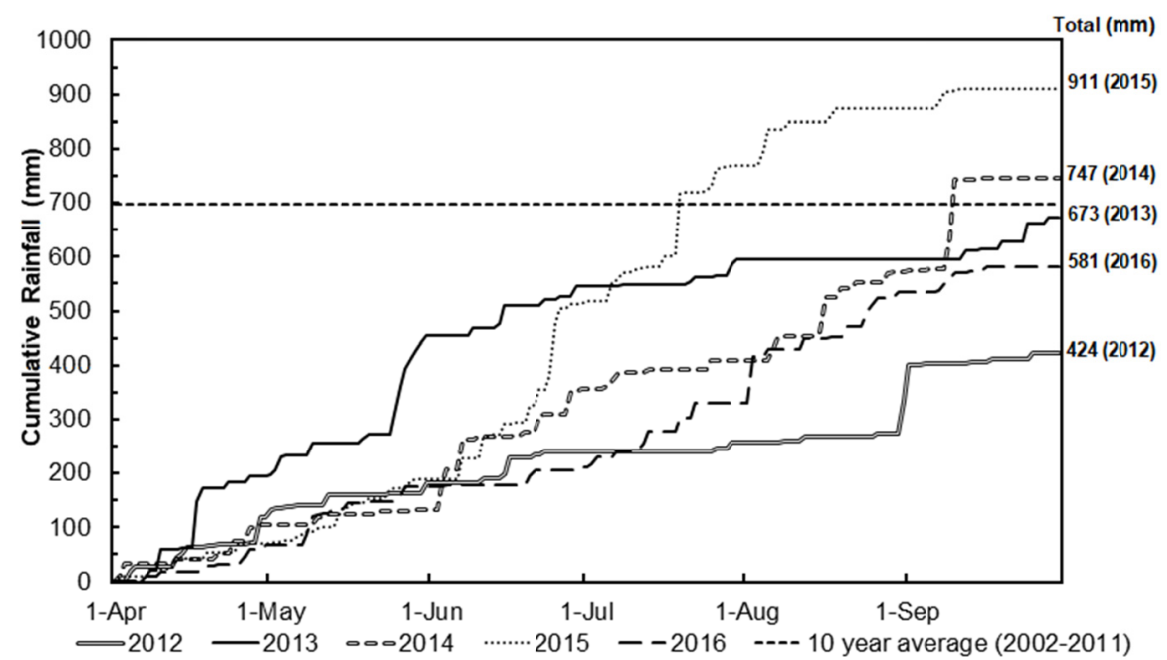

Figure 2. Cumulative precipitation during the 2012 to 2016 growing seasons and the 10 (2002 to 2011) year average $(699 \mathrm{~mm})$ at the Greenley Memorial Research Center near Novelty, Missouri

Table 2. VT (Abendroth et al. 2011) stage or later corn plant heights of gypsum treatments for all field trials from 2012 to 2014

\begin{tabular}{|c|c|c|c|c|}
\hline \multirow{2}{*}{ Trial \# } & \multirow{2}{*}{ Treatment } & \multicolumn{3}{|c|}{ Cropping season } \\
\hline & & 2012 & 2013 & 2014 \\
\hline \multirow{7}{*}{$\begin{array}{l}\text { 无 } \\
\text { 吾 } \\
\underline{F}\end{array}$} & $\mathrm{CTRL}^{\dagger \dagger \dagger}$ & 164 & 202 & 224 \\
\hline & S-LO & 158 & 208 & 232 \\
\hline & S-HI & 163 & 208 & 227 \\
\hline & D-NO & 171 & 204 & 238 \\
\hline & D-LO & 170 & 201 & 248 \\
\hline & D-HI & 167 & 202 & 181 \\
\hline & $\mathrm{LSD}_{(\mathrm{P} \leq 0.10)}$ & 10 & $\mathrm{NS}^{\dagger}$ & 61 \\
\hline \multirow{7}{*}{ 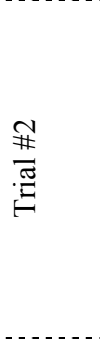 } & CTRL $^{--}$ & $\cdots$ & 246 & 266 \\
\hline & S-LO & --- & 260 & 271 \\
\hline & S-HI & --- & 233 & 267 \\
\hline & D-NO & --- & 248 & 274 \\
\hline & D-LO & --- & 242 & 273 \\
\hline & D-HI & --- & 244 & 269 \\
\hline & $\operatorname{LSD}_{(\mathrm{P} \leq 0.10)}$ & - & 14 & $\mathrm{NS}$ \\
\hline \multirow{7}{*}{ 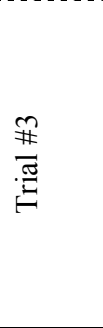 } & CTRL & - & -.. & 251 \\
\hline & S-LO & --- & --- & 255 \\
\hline & S-HI & --- & --- & 238 \\
\hline & $\mathrm{D}-\mathrm{NO}$ & --- & --- & 253 \\
\hline & D-LO & --- & --- & 262 \\
\hline & D-HI & --- & --- & 259 \\
\hline & $\mathrm{LSD}_{(\mathrm{P} \leq 0.10)}$ & - & -.. & $\mathrm{NS}$ \\
\hline
\end{tabular}

Note. ${ }^{\dagger}$ NS denotes no significance difference at $\mathrm{P} \leq 0.10 ;{ }^{\dagger}$ Field site was not established and no data were collected; ${ }^{\dagger \dagger}$ Abbreviations: CTRL, Control; S-LO, Surface $2.9 \mathrm{Mg} \mathrm{ha}^{-1}$; S-HI, Surface $5.2 \mathrm{Mg} \mathrm{ha}^{-1}$.

D-NO, Deep tillage no lime; D-LO, Deep placement 2.9 $\mathrm{Mg} \mathrm{ha}^{-1}$; D-HI, Deep placement $5.2 \mathrm{Mg} \mathrm{ha}^{-1}$. 
Table 3. Corn plant populations of gypsum treatments for all trials from 2012 to 2016

\begin{tabular}{|c|c|c|c|c|c|c|}
\hline \multirow{2}{*}{ Trial \# } & \multirow{2}{*}{ Treatment } & \multicolumn{5}{|c|}{ Cropping season } \\
\hline & & 2012 & 2013 & 2014 & 2015 & 2016 \\
\hline \multirow{8}{*}{ 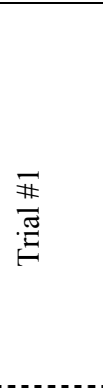 } & & ------- & ------ & --- No. $h$ & ---------- & --------- \\
\hline & $\mathrm{CTRL}^{\dagger \dagger \dagger}$ & 74,400 & 66,000 & 70,200 & 62,800 & 74,000 \\
\hline & S-LO & 76,900 & 72,300 & 66,800 & 59,900 & 77,300 \\
\hline & S-HI & 76,900 & 70,100 & 69,800 & 61,100 & 72,000 \\
\hline & D-NO & 64,400 & 66,400 & 67,600 & 61,600 & 67,600 \\
\hline & D-LO & 63,100 & 66,000 & 67,600 & 61,600 & 66,000 \\
\hline & D-HI & 70,100 & 68,300 & 67,100 & 62,300 & 62,200 \\
\hline & $\operatorname{LSD}_{(\mathrm{P} \leq 0.10)}$ & 9,300 & $\mathrm{NS}^{\dagger}$ & NS & 2,100 & 7,400 \\
\hline \multirow{7}{*}{ 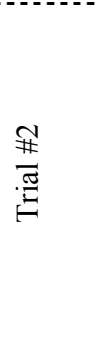 } & CTRL & --7 & 66,600 & 65,500 & 62,100 & 66,100 \\
\hline & S-LO & --- & 67,800 & 69,400 & 64,900 & 68,700 \\
\hline & S-HI & --- & 67,800 & 68,300 & 64,600 & 70,800 \\
\hline & D-NO & --- & 65,900 & 62,400 & 61,300 & 68,300 \\
\hline & D-LO & --- & 64,900 & 66,400 & 63,300 & 67,800 \\
\hline & D-HI & --- & 66,500 & 62,400 & 61,800 & 68,900 \\
\hline & $\operatorname{LSD}_{(\mathrm{P} \leq 0.10)}$ & -- & NS & 6,000 & NS & $\mathrm{NS}$ \\
\hline \multirow{7}{*}{$\frac{\cong}{\#}$} & CTRL & ( & (-- & 61,400 & 75,900 & 74,500 \\
\hline & S-LO & --- & --- & 50,100 & 75,300 & 73,000 \\
\hline & S-HI & --- & --- & 57,100 & 73,000 & 66,500 \\
\hline & D-NO & --- & --- & 62,200 & 74,200 & 77,000 \\
\hline & D-LO & --- & --- & 61,000 & 73,900 & 74,900 \\
\hline & D-HI & --- & --- & 61,800 & 72,100 & 77,000 \\
\hline & $\operatorname{LSD}_{(\mathrm{P} \leq 0.10)}$ & -- & -- & NS & 3,500 & 8,300 \\
\hline
\end{tabular}

Note. ${ }^{\dagger}$ NS denotes no significance difference at $\mathrm{P} \leq 0.10 ;{ }^{\dagger \dagger}$ Field site was not established and no data were collected; ${ }^{\dagger \dagger}$ Abbreviations: CTRL, Control; S-LO, Surface $2.9 \mathrm{Mg} \mathrm{ha}^{-1}$; S-HI, Surface $5.2 \mathrm{Mg} \mathrm{ha}^{-1}$.

D-NO, Deep tillage no lime; D-LO, Deep placement 2.9 $\mathrm{Mg} \mathrm{ha}^{-1}$; D-HI, Deep placement 5.2 $\mathrm{Mg} \mathrm{ha}^{-1}$.

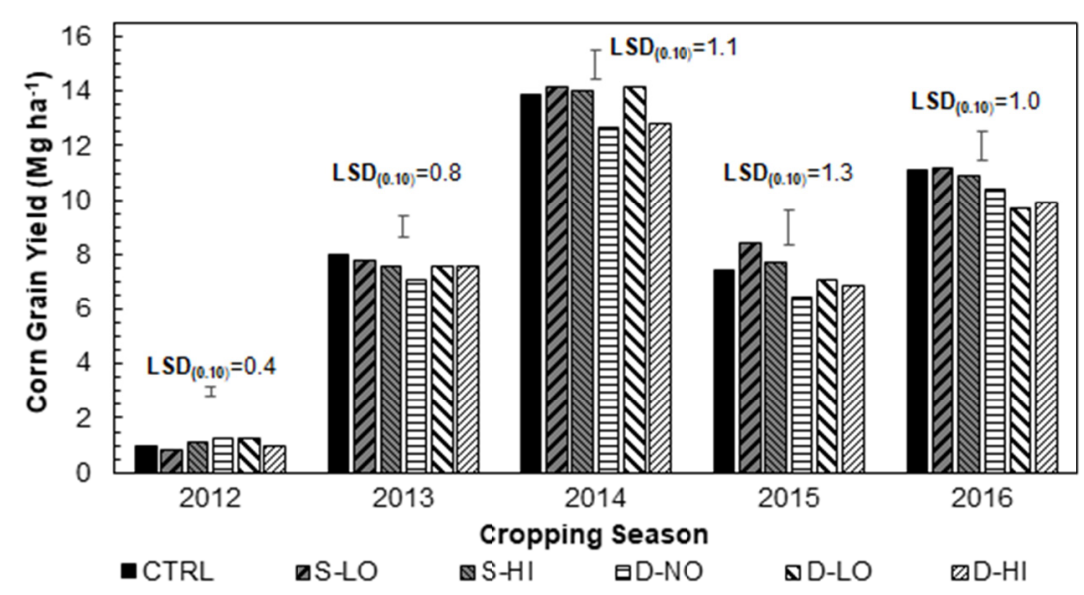

Figure 3. Trial \#1 corn grain yields $\left(\mathrm{Mg} \mathrm{ha}^{-1}\right)$ for gypsum treatments from 2012 to $2016 . \mathrm{LSD}_{(0.10)}$ is the least

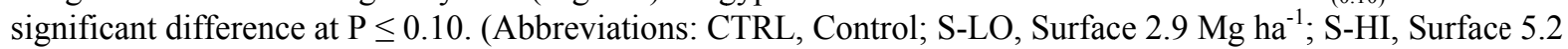
$\mathrm{Mg} \mathrm{ha}^{-1}$; D-NO, Deep tillage no lime; D-LO, Deep placement 2.9 $\mathrm{Mg} \mathrm{ha}^{-1}$; D-HI, Deep placement $5.2 \mathrm{Mg} \mathrm{ha}^{-1}$ ) 


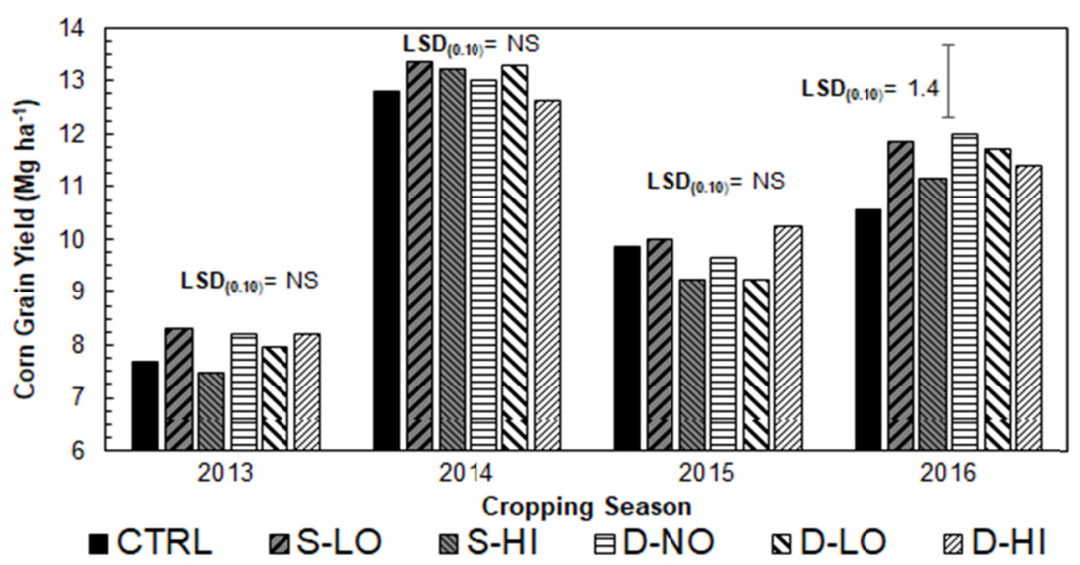

Figure 4. Trial \#2 corn grain yields $\left(\mathrm{Mg} \mathrm{ha}^{-1}\right)$ for gypsum treatments from 2013 to 2016 . $\mathrm{LSD}_{(0.10)}$ is the least significant difference at $\mathrm{P} \leq 0.10$. (Abbreviations: CTRL, Control; S-LO, Surface $2.9 \mathrm{Mg}^{-1}{ }^{-1}$; S-HI, Surface 5.2 $\mathrm{Mg} \mathrm{ha}^{-1}$; D-NO, Deep tillage no lime; D-LO, Deep placement 2.9 $\mathrm{Mg} \mathrm{ha}^{-1}$; D-HI, Deep placement 5.2 $\mathrm{Mg} \mathrm{ha}^{-1}$ )

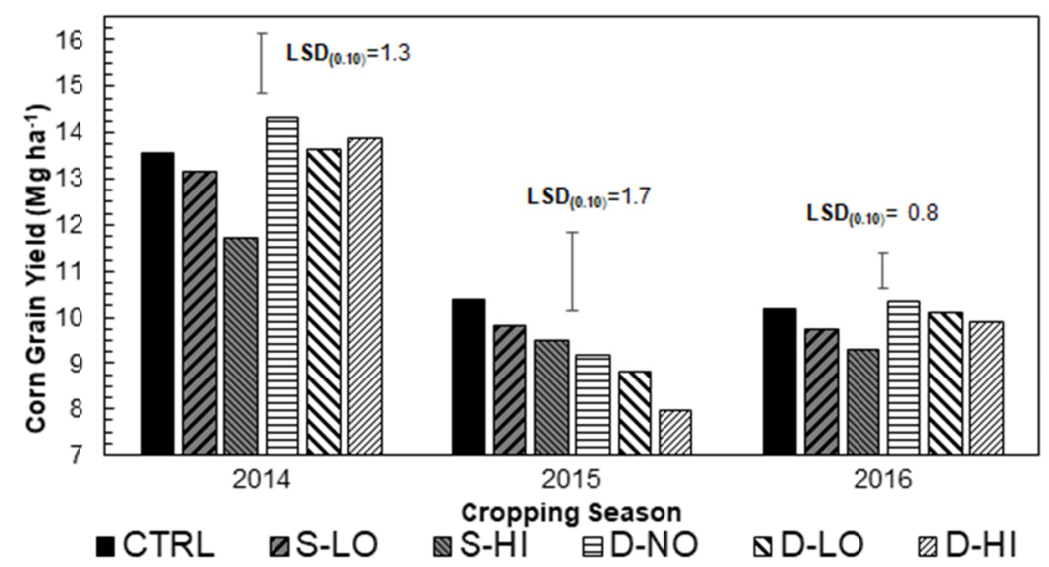

Figure 5. Trial \#3 corn grain yields $\left(\mathrm{Mg} \mathrm{ha}^{-1}\right)$ for gypsum treatments from 2013 to 2016 . $\operatorname{LSD}_{(0.10)}$ is the least significant difference at $\mathrm{P} \leq 0.10$. (Abbreviations: CTRL, Control; S-LO, Surface $2.9 \mathrm{Mg} \mathrm{ha}^{-1}$; S-HI, Surface 5.2 $\mathrm{Mg} \mathrm{ha}^{-1}$; D-NO, Deep tillage no lime; D-LO, Deep placement 2.9 $\mathrm{Mg} \mathrm{ha}^{-1}$; D-HI, Deep placement 5.2 $\mathrm{Mg} \mathrm{ha}^{-1}$ )

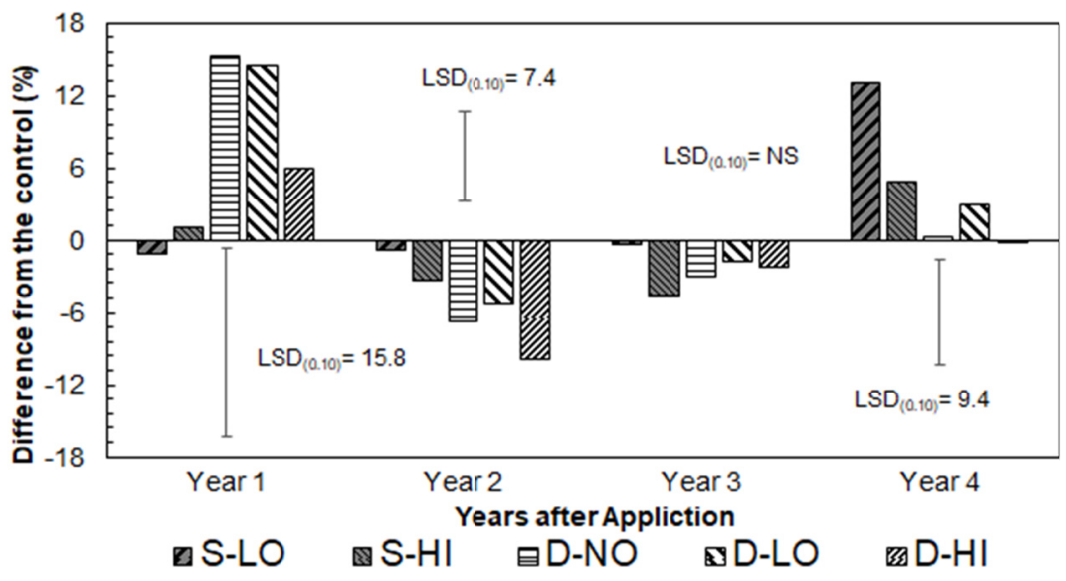

Figure 6. Corn grain yield difference from control plots (\%) of gypsum treatments for all trials 1 to 4 years after treatments. $\operatorname{LSD}_{(0.10)}$ is the least significant difference at $\mathrm{P} \leq 0.10$. (Abbreviations: $\mathrm{S}-\mathrm{LO}$, Surface $2.9 \mathrm{Mg} \mathrm{ha}^{-1}$;

S-HI, Surface 5.2 $\mathrm{Mg} \mathrm{ha}^{-1}$; D-NO, Deep tillage no lime; D-LO, Deep placement 2.9 $\mathrm{Mg} \mathrm{ha}^{-1}$; D-HI, Deep placement $5.2 \mathrm{Mg} \mathrm{ha}^{-1}$ ) 
No significant differences in corn grain yields from gypsum treatments compared to the control plots were observed for most of the experimental years of Trial \#2 (Figure 4). In 2014, surface applied of gypsum at $5.2 \mathrm{Mg}$ $\mathrm{ha}^{-1}$ reduced corn yield by $1.8 \mathrm{Mg} \mathrm{ha}^{-1}$ compared to the control treatment in Trial \#3 (Figure 5). Two years after application, deep vertical placed gypsum at $5.2 \mathrm{Mg} \mathrm{ha}^{-1}$ reduced corn yields by $2.4 \mathrm{Mg} \mathrm{ha}^{-1}$ compared to the control treatment in Trial \#3. In the third experimental year, corn yields were reduced by $0.9 \mathrm{Mg} \mathrm{ha}^{-1}$ from gypsum surface applied at $5.2 \mathrm{Mg} \mathrm{ha}^{-1}$ compared to the control treatment in Trial \#3.

To better assess the residual effects of gypsum on corn grain yields, differences from control plots were combined and averaged for all three trials (Figure 6). During the first year following application, deep vertical placement had no significant effects on grain yield. Two years after application, only deep vertical placement at $5.2 \mathrm{Mg} \mathrm{ha}^{-1}$ significantly decreased yields by $9.9 \%$. Grain yields were similar to control plots three years after application. However, four years after surface applications of gypsum at $2.9 \mathrm{Mg} \mathrm{ha}^{-1}$ had a $13 \%$ increase in corn grain yields.

\subsubsection{Soybean}

Soybean plant heights were recorded in August to September each year and are reported in Table 4. Surface applied gypsum at $2.9 \mathrm{Mg} \mathrm{ha}^{-1}$ increased soybean plant height $3 \mathrm{~cm}$ for Trial \#1 compared to the non-treated control in 2012. However, no gypsum treatments significantly increased soybean height compared to the control from 2013 to 2015. In Trial \#2, an $11 \mathrm{~cm}$ increase in plant height from a surface application of gypsum at $2.9 \mathrm{Mg}$ $\mathrm{ha}^{-1}$ was observed compared to the control in 2013. This same trial had 8 and $10 \mathrm{~cm}$ shorter plants from a deep vertical placement of gypsum at 2.9 and $5.2 \mathrm{Mg} \mathrm{ha}^{-1}$, respectively, compared to the control. The only significant decrease in plant height compared to the control for Trial \#3 was observed in 2015, where surface applications and deep vertical placement of gypsum at $2.9 \mathrm{Mg} \mathrm{ha}^{-1}$ were 15 and $14 \mathrm{~cm}$, respectively, shorter than the control.

Trial \#1 had no significant differences in soybean plant populations among treatments for all years from 2012 to 2015 , but surface application of gypsum at $2.9 \mathrm{Mg} \mathrm{ha}^{-1}$ increased plant populations by 269,100 plants $\mathrm{ha}^{-1}$ in 2016 (Table 5). Trial \#2 had a significant decrease in plant population of 37,700 and 32,300 plants ha ${ }^{-1}$ for deep vertical placement treatments of 2.9 and $5.2 \mathrm{Mg} \mathrm{ha}^{-1}$, respectively, in 2014. However, surface and deep vertical placement treatments of $5.2 \mathrm{Mg} \mathrm{ha}^{-1}$ had 53,800 and 64,500 plants $\mathrm{ha}^{-1}$, respectively, greater soybean plant populations in 2015. For Trial \#3, deep vertically placed gypsum at $5.2 \mathrm{Mg} \mathrm{ha}^{-1}$ had lower plant populations $\left(43,100\right.$ plants $\left.\mathrm{ha}^{-1}\right)$ compared to the control in 2014 , while a surface application at $2.9 \mathrm{Mg} \mathrm{ha}^{-1}$ had a plant population that was 32,300 plants ha ${ }^{-1}$ less than the control in 2016.

Soybean yields varied greatly between crop years depending on seasonal precipitation (Figure 2). Yields from gypsum treatments for soybean are presented in Figures 7 to 10. For the first year of Trial \#1, deep vertical placement of gypsum at $5.2 \mathrm{Mg} \mathrm{ha}^{-1}$ had yields that were $0.3 \mathrm{Mg} \mathrm{ha}^{-1}$ lower than the control (Figure 7). However, no significant effects from gypsum treatments were observed in the second, third, or fourth year after application compared to control plots. In 2016 (five years after application), all gypsum treatments had soybean yields that were less than the non-treated control.

For Trial \#2, gypsum had no effect on soybean yields the first season after treatment (Figure 8). By the second year after treatment, deep vertical placed gypsum at 2.9 and $5.2 \mathrm{Mg} \mathrm{ha}^{-1}$ for Trial \#2 had grain yields that were $0.7 \mathrm{Mg} \mathrm{ha}^{-1}$ less than the control (Figure 8). However, no difference among gypsum treatments were observed in the following two years of treatment (2015 and 2016) for Trial \#2. Gypsum treatments on Trial \#3 had no effects on yield compared to the control for all three experimental years following establishment (Figure 9).

Percent differences from control plots were combined over years after application for all field trials to evaluate the residual effects of gypsum treatments (Figure 10). In the first year of application, deep vertical placement at $5.2 \mathrm{Mg} \mathrm{ha}^{-1}$ had soybean yields that were $9.8 \%$ less than the control. In the second year after application, deep vertically placed gypsum at 2.9 and $5.2 \mathrm{Mg} \mathrm{ha}^{-1}$ had yields that were 6.4 to $6.5 \%$ less than the control. No significant differences among treatments were observed the third year after application; however, deep vertical placement decreased soybean yields up to $18.5 \%$.

\section{Discussion}

Surface applying and deep banding gypsum to poorly-drained claypan soils in a conservation tillage system in Northeast Missouri did not consistently increase corn and soybean yields. This lack of response is contrary to some research that has found positive yield responses to applied gypsum or gypsum industrial byproducts (e.g., Chun et al., 2001; Chen et al., 2005,), but others have found no or inconsistent increases in agronomic yields (DeSutter et al., 2014; Kost et al., 2014). Lack of response to gypsum was most likely caused by the low levels of $\mathrm{Al}^{+3}$ in the surface soil and the limited effect of gypsum in altering the soil $\mathrm{pH}_{\mathrm{s}}$. This was supported by Farina 
and Channon (1988) which concluded that gypsum applications are only effective when $\mathrm{Al}^{+3}$ exceeds Ca in the soil. Excessive salinity caused by banding a high rate of gypsum-related byproducts, such as flue gas desulfurization gypsum, may also reduce plant growth especially under poor drainage conditions when the salts are not leached out of the rooting zone (Wang \& Yang, 2018). Banding gypsum may further increase salinity in the zone where the gypsum was placed.

Past increases in crop yield reported by Farina et al. (2000a) from deep placement of gypsum on acidic soils were not observed in this study. This may in part be due to the initially high soil test Ca levels and greater overall soil fertility found in these claypan soils (Table 1) along with smaller levels of $\mathrm{Al}^{+3}$ in the soil solution. Caires et al. (2011) found no significant increases in soybean yields following gypsum amendments 0 to 10 years after application. Moreover, previous research indicated that soybean production was strongly affected by the gypsum content in soil and yields can be significantly reduced when high levels of gypsum are present (Mardoud, 1980). In addition, past research by Tupper et al. (1987) suggests that deep tillage of soils with dense subsoils can result in greater exposure to subsoil acidity if the acidity is not corrected. The deep tillage effects along with lack of changes to $\mathrm{pH}$ and possible adverse effects from gypsum related to increased salinity may have resulted in yield reductions in four of the 12 crop years.

Table 4. Late season soybean plant heights of gypsum treatments for all field trials from 2012 to 2015

\begin{tabular}{|c|c|c|c|c|c|}
\hline \multirow{2}{*}{ Trial \# } & \multirow{2}{*}{ Treatment } & \multicolumn{4}{|c|}{ Cropping season } \\
\hline & & 2012 & 2013 & 2014 & 2015 \\
\hline \multirow{8}{*}{$\begin{array}{l}\text { \# } \\
. \stackrel{\Xi}{\Xi} \\
ت\end{array}$} & & ------ & -------- & m ----- & 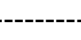 \\
\hline & $\mathrm{CTRL}^{\dagger \dagger \dagger}$ & 53 & 70 & 99 & 83 \\
\hline & S-LO & 56 & 67 & 100 & 87 \\
\hline & S-HI & 55 & 67 & 102 & 83 \\
\hline & D-NO & 55 & 68 & 98 & 79 \\
\hline & D-LO & 55 & 69 & 107 & 83 \\
\hline & D-HI & 54 & 66 & 98 & 77 \\
\hline & $\operatorname{LSD}_{(\mathrm{P} \leq 0.10)}$ & 3 & $\mathrm{NS}^{\dagger}$ & 8 & 9 \\
\hline \multirow{7}{*}{$\frac{\cong}{\#}$} & CTRL & $--^{\dagger}$ & 75 & 99 & 61 \\
\hline & S-LO & --- & 86 & 98 & 53 \\
\hline & S-HI & --- & 77 & 93 & 58 \\
\hline & $\mathrm{D}-\mathrm{NO}$ & --- & 72 & 91 & 57 \\
\hline & D-LO & --- & 75 & 91 & 53 \\
\hline & D-HI & -- & 73 & 89 & 61 \\
\hline & $\operatorname{LSD}_{(\mathrm{P} \leq 0.10)}$ & --- & 9 & 8 & 8 \\
\hline \multirow{7}{*}{ 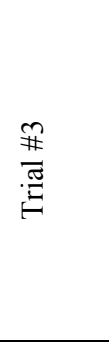 } & CTRL & --- & --- & 98 & 84 \\
\hline & S-LO & --- & --- & 107 & 69 \\
\hline & S-HI & --- & --- & 100 & 75 \\
\hline & $\mathrm{D}-\mathrm{NO}$ & --- & --- & 100 & 72 \\
\hline & D-LO & --- & --- & 100 & 70 \\
\hline & D-HI & -- & --- & 91 & 74 \\
\hline & $\operatorname{LSD}_{(\mathrm{P} \leq 0.10)}$ & --- & --- & 10 & 10 \\
\hline
\end{tabular}

Note. ${ }^{\dagger}$ NS denotes no significance difference at $\mathrm{P} \leq 0.10 ;{ }^{\dagger \dagger}$ Field site was not established and no data were collected; ${ }^{\dagger \dagger}$ Abbreviations: CTRL, Control; S-LO, Surface $2.9 \mathrm{Mg} \mathrm{ha}^{-1}$; S-HI, Surface $5.2 \mathrm{Mg} \mathrm{ha}^{-1}$.

D-NO, Deep tillage no lime; D-LO, Deep placement $2.9 \mathrm{Mg} \mathrm{ha}^{-1}$; D-HI, Deep placement $5.2 \mathrm{Mg} \mathrm{ha}^{-1}$. 
Table 5. Soybean plant population of gypsum treatments for all trials from 2012 to 2016

\begin{tabular}{|c|c|c|c|c|c|c|}
\hline \multirow{2}{*}{ Trial \# } & \multirow{2}{*}{ Treatment } & \multicolumn{5}{|c|}{ Cropping season } \\
\hline & & 2012 & 2013 & 2014 & 2015 & 2016 \\
\hline \multirow{8}{*}{ 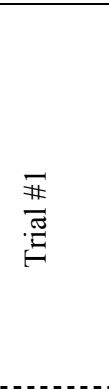 } & & (------ & - & ---- No he & 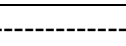 & ---------. \\
\hline & $\mathrm{CTRL}^{\dagger \dagger \dagger}$ & 462,800 & 376,700 & 226,000 & 269,100 & 592,000 \\
\hline & S-LO & 538,200 & 376,700 & 247,600 & 258,300 & 861,100 \\
\hline & S-HI & 549,000 & 333,700 & 269,100 & 301,400 & 635,100 \\
\hline & D-NO & 484,400 & 355,200 & 236,800 & 269,100 & 742,700 \\
\hline & D-LO & 538,200 & 344,400 & 236,800 & 247,600 & 753,500 \\
\hline & D-HI & 441,300 & 387,500 & 269,100 & 279,900 & 678,100 \\
\hline & $\operatorname{LSD}_{(\mathrm{P} \leq 0.10)}$ & $\mathrm{NS}^{\dagger}$ & NS & NS & NS & 225,400 \\
\hline & CTRL & $--{ }^{\dagger}$ & 452,100 & 215,300 & 193,800 & 656,600 \\
\hline \multirow{6}{*}{$\frac{\mathbb{\#}}{\stackrel{\#}{\Xi}}$} & S-LO & --- & 419,800 & 209,900 & 215,300 & 559,700 \\
\hline & S-HI & --- & 387,500 & 204,500 & 247,600 & 710,400 \\
\hline & D-NO & --- & 344,400 & 188,400 & 215,300 & 688,900 \\
\hline & D-LO & --- & 452,100 & 177,600 & 226,000 & 742,700 \\
\hline & D-HI & --- & 387,500 & 183,000 & 258,300 & 678,100 \\
\hline & $\operatorname{LSD}_{(\mathrm{P} \leq 0.10)}$ & --- & 90,400 & 30,600 & 44,000 & NS \\
\hline \multirow{7}{*}{$\frac{\cong}{\#}$} & CTRL & -- & -- & 269,100 & 290,600 & 839,600 \\
\hline & S-LO & --- & --- & 258,300 & 258,300 & 861,100 \\
\hline & S-HI & --- & --- & 247,600 & 226,000 & 807,300 \\
\hline & D-NO & --- & --- & 247,600 & 279,900 & 882,600 \\
\hline & D-LO & --- & --- & 236,800 & 269,100 & 839,600 \\
\hline & D-HI & --- & --- & 226,000 & 279,900 & 904,200 \\
\hline & $\operatorname{LSD}_{(\mathrm{P} \leq 0.10)}$ & --- & --- & 39,300 & 58,700 & NS \\
\hline
\end{tabular}

Note. ${ }^{\dagger}$ NS denotes no significance difference at $\mathrm{P} \leq 0.10 ;{ }^{\dagger \dagger}$ Field site was not established and no data were collected; ${ }^{\dagger \dagger}$ Abbreviations: CTRL, Control; S-LO, Surface 2.9 $\mathrm{Mg} \mathrm{ha}^{-1}$; S-HI, Surface $5.2 \mathrm{Mg} \mathrm{ha}^{-1}$.

D-NO, Deep tillage no lime; D-LO, Deep placement 2.9 $\mathrm{Mg} \mathrm{ha}^{-1}$; D-HI, Deep placement 5.2 $\mathrm{Mg} \mathrm{ha}^{-1}$.

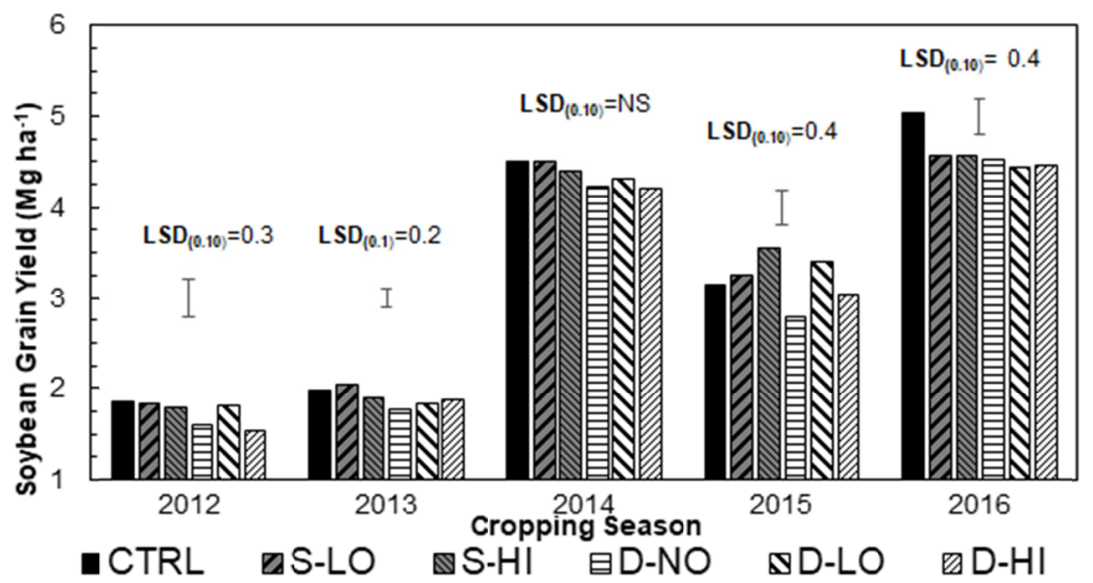

Figure 7. Trial \#1 soybean yields $\left(\mathrm{Mg} \mathrm{ha}^{-1}\right)$ for gypsum treatments from 2012 to $2016 . \mathrm{LSD}_{(0.10)}$ is the least significant difference at $\mathrm{P} \leq 0.10$. (Abbreviations: CTRL, Control; S-LO, Surface $2.9 \mathrm{Mg} \mathrm{ha}^{-1}$; S-HI, Surface 5.2 $\mathrm{Mg} \mathrm{ha}^{-1}$; D-NO, Deep tillage no lime; D-LO, Deep placement 2.9 $\mathrm{Mg} \mathrm{ha}^{-1}$; D-HI, Deep placement 5.2 $\mathrm{Mg} \mathrm{ha}^{-1}$ ) 


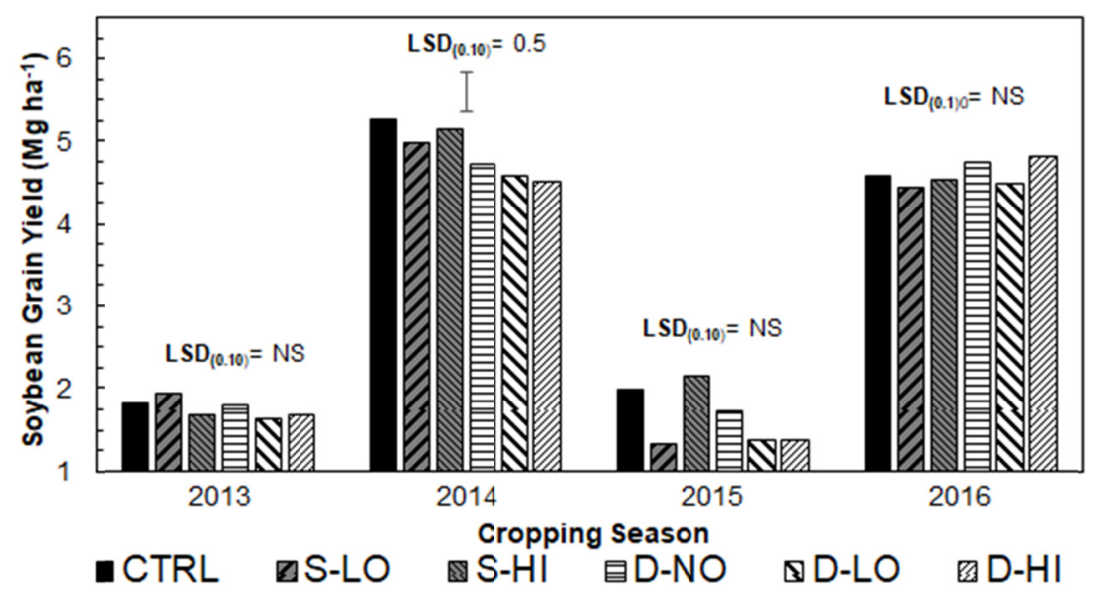

Figure 8. Trial \#2 soybean yields $\left(\mathrm{Mg} \mathrm{ha}^{-1}\right)$ for gypsum treatments from 2013 to 2016 . $\mathrm{LSD}_{(0.10)}$ is the least significant difference at $\mathrm{P} \leq 0.10$. (Abbreviations: CTRL, Control; S-LO, Surface $2.9 \mathrm{Mg}^{-1} \mathrm{~g}^{-1}$; S-HI, Surface 5.2 $\mathrm{Mg} \mathrm{ha}^{-1}$; D-NO, Deep tillage no lime; D-LO, Deep placement 2.9 $\mathrm{Mg} \mathrm{ha}^{-1}$; D-HI, Deep placement 5.2 $\mathrm{Mg} \mathrm{ha}^{-1}$ )

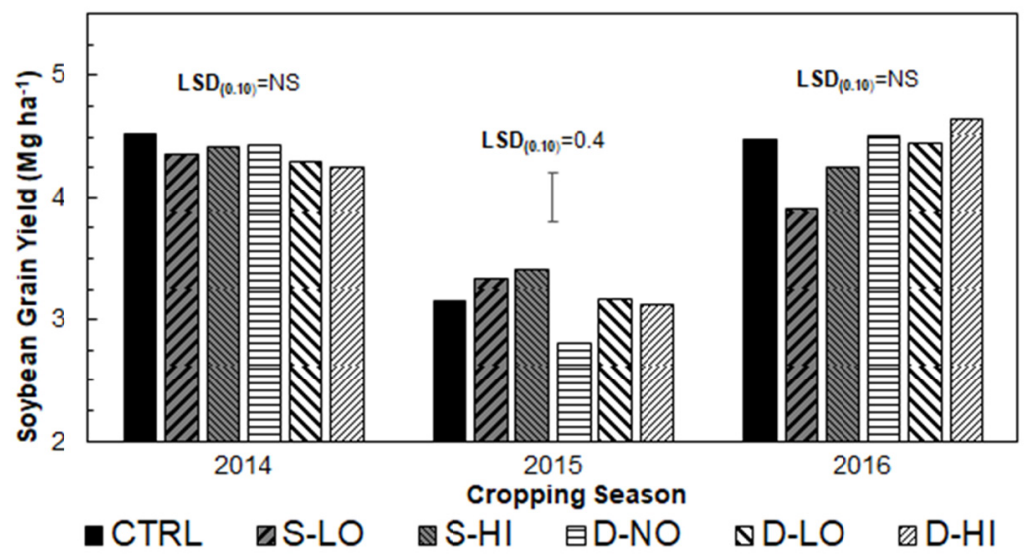

Figure 9. Trial \#3 soybean yields $\left(\mathrm{Mg} \mathrm{ha}^{-1}\right)$ for gypsum treatments from 2014 to 2016 . $\mathrm{LSD}_{(0.10)}$ is the least significant difference at $\mathrm{P} \leq 0.10$. (Abbreviations: CTRL, Control; S-LO, Surface $2.9 \mathrm{Mg}^{-1}{ }^{-1}$; S-HI, Surface 5.2 $\mathrm{Mg} \mathrm{ha}^{-1}$; D-NO, Deep tillage no lime; D-LO, Deep placement 2.9 $\mathrm{Mg} \mathrm{ha}^{-1}$; D-HI, Deep placement 5.2 $\mathrm{Mg} \mathrm{ha}{ }^{-1}$ )

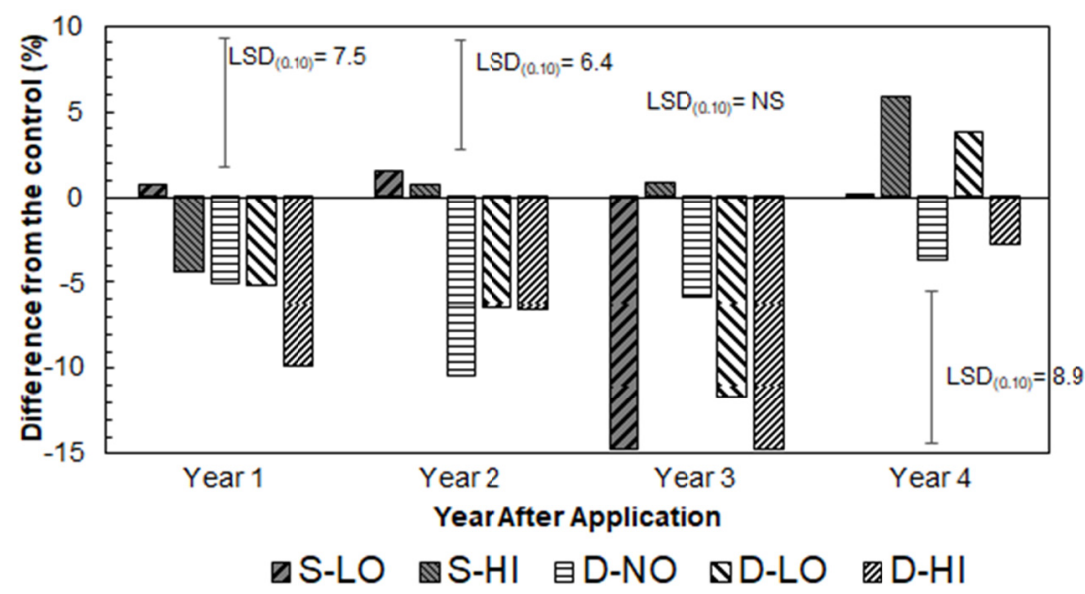

Figure 10. Soybean yield difference from control plots (\%) for all trials 1 to 4 years after gypsum treatments. $\mathrm{LSD}_{(0.10)}$ is the least significant difference at $\mathrm{P} \leq 0.10$. (Abbreviations: S-LO, Surface $2.9 \mathrm{Mg} \mathrm{ha}^{-1}$; S-HI, Surface 5.2 $\mathrm{Mg} \mathrm{ha}^{-1}$; D-NO, Deep tillage no lime; D-LO, Deep placement 2.9 $\mathrm{Mg} \mathrm{ha}^{-1}$; D-HI, Deep placement 5.2 $\mathrm{Mg} \mathrm{ha}^{-1}$ ) 


\section{Conclusions}

Previous research on surface or incorporated gypsum applications has indicated possible benefits of this application method to ameliorate subsoil acidity issues and increase crop production, especially in highly-weathered soils. However, less research has established the efficacy of this placement method in less-weathered soils, especially when the gypsum was deep vertically banded. This research suggests that deep vertical placement application of gypsum to claypan soils under a conservation tillage system does not increase corn or soybean yields, but may actually reduce crop yields when this material is placed in a deep band at the rates evaluated in this experiment.

The effects of gypsum applications on soil acidity and crop production may also require several years to fully assess. Continued long-term analysis of field sites could obtain a better understanding of the effects of treatments and how they interact with climate and different depths to the more acidic claypan that occurs across these landscapes.

Alterations in the design of the custom built shank for deep banded placement may be needed to incorporate the gypsum into a larger soil volume in the subsoil to possibly avoid reductions in yields caused by the high concentration of gypsum in the band. However, these alterations may require greater energy to pull the shank through the soil and the initial results reported in this research indicate that deep banding gypsum may not be effective in increasing crop production for these soils. A possible combination of simultaneous surface gypsum and deep agricultural lime banding could be explored to assess its effectiveness since there was a small and inconsistent improvement in plant growth with the surface gypsum application, especially in the soybean crop.

\section{References}

Abendroth, L. J., Elmore, R. W., Boyer M. J., \& Marlay, S. K. (2011). Corn growth and development. Iowa State University Extension, Ames, IA.

Abruna, F., Pearson, R., W., \& Elkins, C. B. (1958). Quantitative evaluation of soil reaction and base status changes resulting from field application of residually acid-forming nitrogen fertilizers. Soil Sci. Soc. Am. J., 22(6), 539-542. https://doi.org/10.2136/sssaj1958.03615995002200060017x

Adeoye, K. B., \& Singh, L. (1984). The effect of bulk application of lime under two tillage depths on soil pH and crop yield. Plant Soil, 85(2), 295-297. https://doi.org/10.1007/BF02139634

Blumenschein, T. G., Nelson, K. A., \& Motavalli, P. P. (2018). Impact of a new deep vertical lime placement practice on corn and soybean production in conservation tillage systems. Agronomy, 8(104), 1-17. https://doi.org/10.3390/agronomy8070104

Buchholz, D. D., Brown, J. R., Garrett, J. D., Hanson, R. G., \& Wheaton, H. N. (1983). Soil test interpretations and recommendations handbook. Department of Agronomy, College of Agriculture, University of Missouri, Columbia, MO.

Caires, E. F., Maschietto, E. H. G., Garbuio, F. J., Churka, S., \& Joris, H. A. W. (2011). Surface application of gypsum in low acidic Oxisol under no-till cropping system. Sci. Agric. (Piracicaba, Braz.), 68(2). https://doi.org/10.1590/S0103-90162011000200011

Chen, L., \& Dick, W. A. (2011). Gypsum as an agricultural amendment: General use guidelines. The Ohio State University Extension, Columbus, OH. Retrieved May 14, 2018, from https://fabe.osu.edu/sites/fabe/files/ imce/files/Soybean/Gypsum\%20Bulletin.pdf

Chen, L., Dick, W. A., \& Nelson, Jr. S. (2005). Flue gas desulfurization products as sulfur sources for alfalfa and soybean. Agron. J., 97, 265-271.

Chun, S., Nishiyama, M., \& Matsumato, S. (2001). Sodic soils reclaimed with by-product from flue gas desulfurization: Corn productivity and soil quality. Environ. Pollut., 114, 453-459. https://doi.org/10.1016/ S0269-7491(00)00226-8

DeSutter, T. M., Cihacek, L. J., \& Rahman, S. (2014). Application of flue gas desulfurization gypsum and its impact on wheat grain and soil chemistry. J. Environ. Qual., 43, 303-311. https://doi.org/10.2134/jeq2012. 0084

Farina, M. P. W., \& Channon, P. (1988). Acid-subsoil amelioration: I. A comparison of several mechanical procedures. Soil Sci. Soc. Am. J., 52(1), 169-175. https://doi.org/10.2136/sssaj1988.036159950052000 $1000 x$ 
Farina, M. P. W., Channon, P., \& Thibaud, G. R. (2000a). A comparison of strategies for ameliorating subsoil acidity: II. Long-term soil effects. Soil Sci. Soc. Am. J., 64(2), 652-658. https://doi.org/10.2136/sssaj2000.6 42652x

Farina, M. P. W., Channon, P., \& Thibaud, G. R. (2000b). A comparison of strategies for ameliorating subsoil acidity: I. Long-term growth effects. Soil Sci. Soc. Am. J., 64(2), 646-651. https://doi.org/10.2136/sssaj2000. $642652 x$

Ferguson, H. J., (1995). Soil survey of Macon County, Missouri. USDA, Soil Conserv. Service. Washington, DC.

Godsey, C. B., Pierzynski, G. M., Mengel, D. B., \& Lamond, R. E. (2007). Management of soil acidity in no-till production systems through surface application of lime. Agron. J., 99(3), 764-772. https://doi.org/10.2134/ agronj2006.0078

Kost, D., Chen, L., Guo, X., Tian, Y, Ladwig, K., \& Dick, W. A. (2014). Effects of flue gas desulfurization and mined gypsums on soil properties and on hay and corn growth in eastern Ohio. J. Environ. Qual, 43, 312-321. https://doi.org/10.2134/jeq2012.0157

Kuylenstierna, J. C. I., Rodhe, H., Cinderby, S., \& Hicks, K. (2001). Acidification in developing countries: Ecosystem sensitivity and the critical load approach on a global scale AMBIO: A Journal of the Human Environ., 30(1), 20-28.

Mardoud, T. (1982). Gypsiferous soils in the Balikh basin - characteristics and productivity (pp. 308-320). Soil Taxonomy Workshop ACSAD.

Mclay, C., Ritchie, G., Porter, W., \& Cruse, A. (1994). Amelioration of subsurface acidity in sandy soils in low rainfall regions. 2. Changes to soil solution composition following the surface application of gypsum and lime. Soil Res., 32(4), 847-865. https://doi.org/10.1071/SR9940847

Nordstrom, D. K. (1982). The effect of sulfate on aluminum concentrations in natural waters: Some stability relations in the system $\mathrm{Al}_{2} \mathrm{O}_{3}-\mathrm{SO}_{3}-\mathrm{H}_{2} \mathrm{O}$ at $298 \mathrm{~K}$. Geochimica et Cosmochimica Acta, 46(4), 681-692. https://doi.org/10.1016/0016-7037(82)90168-5

Nathan, M., Stecker, J., \& Sun, Y. (2006). Soil testing in Missouri: A guide for conducting soil tests in Missouri. Division of Plant Sciences, College of Agriculture, Food and Natural Resources, University of Missouri.

O’Leary, M. J., \& Rehm, G. W. (1990). Nitrogen and sulfur effects on the yield and quality of corn grown for grain and silage. J. Prod. Agric., 3, 135-140. https://doi.org/10.2134/jpa1990.0135

Rengel, Z. (2003). Handbook of soil acidity. Marcel Dekker Inc, 270 Madison Avenue, New York, NY. https://doi.org/10.1201/9780203912317

Ritchey, K. D., Souza, D. M. G., Lobato, E., \& Correa, O. (1980). Calcium leaching to increase rooting depth in a Brazilian savannah Oxisol. Agron. J., 72, 40-44. https://doi.org/10.2134/agronj1980.00021962007200010 009x

Seim, E. C., Caldwell, A. C., \& Rehm, G. W. (1969). Sulfur response by alfalfa (Medicago sativa L.) on a sulfur-deficient soil. Agron. J., 61, 368-371. https://doi.org/10.2134/agronj1969.00021962006100030009x

SAS Institute Inc. (2013). Base 9.4 Procedures Guide. SAS Institute Inc., Cary, NC.

Sumner, M. E. (1995). Amelioration of subsoil acidity with minimum disturbance. In N. S. Jayawardane, \& B. A. Stewart (Eds.), Subsoil management techniques (pp. 147-186). Advances in Soil Sci., Lewis Publishers, Boca Raton, FL.

Sumner, M. E., Shahandeh, H., Bouton, J., \& Hammel, J. (1986). Amelioration of an acid soil profile through deep liming and surface application of gypsum. Soil Sci. Soc. Am. J., 50(5), 1254-1258. https://doi.org/ 10.2136/sssaj1986.03615995005000050069x

Sumner, M. E., \& Yamada, T. (2002). Farming with acidity. Comm. Soil Sci. Plant Anal., 33, $2467-2496$. https://doi.org/10.1081/CSS-120014461

Toma, M., Sumner, M. E., Weeks, G., \& Saigusa, M. (1999). Long-term effects of gypsum on crop yield and subsoil chemical properties. Soil Sci. Soc. Am. J., 63(4), 891-895. https://doi.org/10.2136/sssaj1999.634 $891 x$

Tupper, G. R., Pringle, III, H. C., Ebelhar, M. W., \& Hamill, J. G. (1987). Soybean yield and economic response to broadcast incorporated and deep band placement of lime on low pH soils. Mississippi Agri. \& Forestry Ext. Station Bulletin, 950, 7. 
Udawatta, R. P., Motavalli, P. P., \& Garrett, H. E. (2004). Phosphorus loss and runoff characteristics in three adjacent agricultural watersheds with claypan soils. J. Environ. Qual., 33, 1709-1719. https://doi.org/ 10.2134/jeq2004.1709

Wallace, A. (1994). Use of gypsum on soil where needed can make agriculture more sustainable. Comm. Soil Sci. Plant Anal, 25, 109-116. https://doi.org/10.1080/00103629409369015

Wang, J., \& Yang, P. (2018). Potential flue gas desulfurization gypsum utilization in agriculture: A comprehensive review. Renewable and Sustainable Energy Reviews, 82, 1969-1978. https://doi.org/ 10.1016/j.rser.2017.07.029

Watts, D. B., \& Dick, W. A. (2014). Sustainable uses of FGD gypsum in agricultural systems: Introduction. $J$. Environ. Qual., 43, 246-252. https://doi.org/10.2134/jeq2013.09.0357

\section{Copyrights}

Copyright for this article is retained by the author(s), with first publication rights granted to the journal.

This is an open-access article distributed under the terms and conditions of the Creative Commons Attribution license (http://creativecommons.org/licenses/by/4.0/). 